ЦЕИ. 2020. 3(12). С. 237-268

ISSN 2619-0877

\title{
Теодора Шек-Брнардич
}

$\mathrm{PhD}$, ведущий научный сотрудник, Институт хорватской истории, Загреб, Хорватия. 10000, Opatička 10, Zagreb. E-mail: teashek@gmail.com

\section{Просвещение на закате Дубровницкой республики: Патриотическое общество (1793-1794)}

\begin{abstract}
Патриотическое общество, основанное высокообразованным аристократом Михо Сорго (1739-1796), являлось первой просветительской организацией в Дубровницкой республике. В отличие от предшествующих гуманистических и барочных обществ, называвшихся «академиями» и занимавшихся вопросами языкознания и литературы, кружок ученых-любителей во главе с Сорго ориентировался на социальный запрос и преследовал практические цели. Такая позиция подразумевала и критичное отношение к современным дубровницким реалиям, а главным образом - к правящей аристократической олигархии, заседавшей в Сенате, обладавшей монополией в политической сфере. И хотя Европа в то время переживала глубокие социальные и политические трансформации, речи о реформировании статичных консервативных кругов Дубровника не было. Поэтому деятельность общества реформаторов оказалась кратковременной, всего один год. В статье представлен анализ академического сообщества Дубровника в XVIII в., исследованы процесс создания и цели Патриотического общества, представлены темы сохранившихся текстов выступлений, рассмотрена деятельность некоторых членов кружка, главным образом роль магната Томо Басельи, проникшегося идеями Просвещения в годы учебы в Швейцарии, Германии и Австрии.
\end{abstract}

Ключевые слова: просвещение, патриотизм, Дубровник, реформы, общественность, публичность

Цитирование: Шек-Брнардич Т. Просвещение на закате Дубровницкой республики: Патриотическое общество (1793-1794). 2020. Вып. 3(12) / гл. ред. О. В. Хаванова. М. : Институт славяноведения РАН ; СПб. : Нестор-История, 2021. C. 237-268. DOI: 10.31168/2619-0877.2020.3.11

Статья подготовлена в рамках проекта IP-2018-01-2539 (EuKor) «Европейские корни модерной Хорватии: трансфер идей в политике и культуре XVIII-XIX вв.» при поддержке Хорватского научного фонда. 
B XVIII в. крошечная Дубровницкая республика была известна

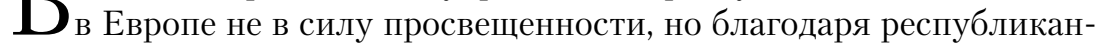
ским свободам. Слава ее была не меньшей, чем у аристократических республик Венеции, Лукки, Генуи и Сан-Марино в Италии, Нидерландов, Швейцарии или Женевы. Их государственное устройство интересовало мыслителей эпохи Просвещения Вольтера и Монтескье, а гражданин Женевы Руссо был сторонником республики и уделял этой теме особое внимание в своих трудах ${ }^{1}$. Власть в Дубровнике столетиями принадлежала узкой группе нобилите$\mathrm{Ta}^{2}$ во главе с князем, который заново избирался каждый месяц. Такая процедура вызывала немалое удивление иностранцев. Помимо Большого и Малого советов, состав которых формировался исключительно из аристократов, особую роль в политической системе играл Сенат ${ }^{3}$. Несомненно, влияла на социум и Римско-католическая церковь, подпитывавшая консервативные настроения. И все же маленькое государство, хотя и наслаждалось стабильностью и не знало внутренних неурядиц, было вынужденно отстаивать свою независимость перед лицом опасных соседей - Венеции и Османской империи 4 К Кроме того, Дубровник был знаменит достижениями культуры и искусства эпохи Возрождения, в особенности в области литературы и театра, и не без оснований назывался «славянскими Афинами». Роковое землетрясение 1667 г. унесло жизни более половины населения и оставило в руинах город, который так никогда и не оправился, хотя и в таком состоянии Дубровник положительно выделялся на фоне запущенной венецианской Далмации. Итальянский натуралист и просветитель Альберто Фортис (1741-1803), который

${ }^{1}$ В XVIII в. классическая республиканская идея испытала существенное влияние со стороны просветителей во главе с французскими энциклопедистами и Руссо. Республику рассматривали как образ жизни, а не альтернативную форму управления, что делало возможным «деполитизированное» функционирование идеи в монархиях. Так, императрица Екатерина II говорила, что у нее «республиканская душа» (l'âme republicaine), несмотря на то, что страна, которой она правила, в силу обширности территории нуждалась в самодержавии. См.: Griffiths 1973: 323. Народное образование считалось средством воспитания подданных, возможностью превратить их в римских граждан и патриотов, готовых пожертвовать собой на благо Отечества. О модальности просвещенного патриотизма в монархиях см.: Shek Brnardić 2010.

2 Janeković Römer 1999, 2015. Такая форма правления называлась наследственной аристократией.

${ }^{3}$ Lonza 2009.

${ }^{4}$ Kunčević 2020. 
некогда открыл Западу этот край в сочинении «Путешествия в Далмацию» ${ }^{5}$, был крайне впечатлен городом во время первого посещения в 1780 г.:

Ах! Здесь так много прекрасного. Архитектура благородна и красива, несмотря на то, что столетие назад город едва не погиб во время землетрясения. Предместья райские и элегантные вопреки тому, что расположены они на отвесных скалах - главном рельефе этого скудного края. Любознательный путешественник также подметит, что и с землей обращаются не в пример лучше, чем в венецианской Далмации, где ее обрабатывают скорее сносно. С формальной точки зрения здесь все лучше: правящие круги напитаны культурой, народ дисциплинирован, спартанское уважение к государственным началам, оригинальность и достоинство причудливым образом чередуются в речах... Что еще я могу сказать? Этот пригожий край наделен всеми благами, о которых можно мечтать и в самом цивилизованном итальянском городе, однако без его неудобств и пороков ${ }^{6}$.

В условиях хрупкого равновесия и соседства с грозными державами - Османской империей и Венецией власти Дубровника были вынуждены зорко следить за положением дел, чтобы избежать распространения неслыханных, прорывных идей, поскольку любое проявление революции или переворот соседние государства использовали бы как повод для ликвидации независимости республики. Поэтому в городе не было ни университета, ни других высших учебных заведений, кроме иезуитского коллегиума, в котором до поступления на службу учились молодые аристократы. Те из них, кто имел редкую финансовую возможность продолжить образование за границей, отправлялись для изучения права в университеты Рима, Болоньи, Сиены и Неаполя. Простолюдины пытались получить стипендии только для освоения редких профессий врача, музыканта или художника. За исключением католической богослужебной литературы, прочие местные и привозные книги подвергались цензуре особой канцелярии при Сенате. Общественных библиотек не было, типографии появились только в 1783 г. и печатали строго определенный набор средневековых литературных произведений и трудов по истории

${ }^{5}$ Fortis A. Viaggio in Dalmazia. Venezia: Presso Alvise Milocco, 1774. Подробнее см.: Вульф 2003: 462-483.

6 Альберто Фортис - трогирскому аристократу Анте-Радошу Микели Виттурио, 24 января 1780 г. Цит. по: Bogišić 1905: 29. 
Дубровника 7 . За исключением концертных залов и театров в городе не было инфраструктуры, которая способствовала бы развитию науки и искусства в духе Просвещения. Кроме того, согласно суждениям не только иностранцев, но и образованных дубровчан ${ }^{8}$, общий уровень знаний - мерило прогресса в Просвещении - и интерес к науке был низким:

Дубровник всегда был богат на ученых людей и знаменитых литераторов, но все они преуспели вне родины, добившись и громкого имени, и доброй славы за границей. И сейчас известны дубровчане, которые живут кто-где в Европе, а в самом Дубровнике царит невежество и малограмотность 9 .

Дубровницкие ученые и литераты (лат. literatus - образованный), в авангарде со славной троицей - физиком Руджером Бошковичем (1711-1787), ньютонистом Бенедиктом Стайем (Стойковичем, 17141801) и переводчиком Раймундом Куничем (1719-1794), прославились за границей, в основном в Италии. Впрочем, развитие публичности и социальных институтов, настолько характерных для XVIII в., было невозможно затормозить и в самом Дубровнике в силу ряда обстоятельств. Отдельные фамилии и представители космополитичной элиты поддерживали новые веяния с Запада, главным образом из Италии, связи с которой были тесны в силу географической и культурной близости ${ }^{10}$. Частные библиотеки пополнялись новейшими запрещенными книгами ${ }^{11}$ : ими обменивались единомышленники, обсуждая разные темы в приватной обстановке салонов и особняков ${ }^{12}$.

7 Shek Brnardić 2013: 212.

8 «Они даже представить не могут, что кто-то, не будучи священником, занимается наукой. Самое неприятное, что можно сказать о человеке, это то, что он пишет книгу». Цит. по: Basiljević 1970: 135. Сам Михо Сорго в речи о славянском языке заметил: «Тому, кто занимается наукой (studiis), не гарантированы награда и почести, доступна лишь похвала неизвестных людей, разбросанных по миру; весь свой пыл этот человек должен направлять в науку, в противном случае его звезда никогда не загорится или быстро погаснет. Как следствие, наши ожидания в этой области завышены, а достижения не велики». Цит. по: Rezar 2000: 54.

9 Донесение анонимного австрийского осведомителя императрице Марии Терезии. 1775/1776 гг. Цит. по: Novak 1978: 139, 141.

10 Венецианское влияние сказалось и в том, что языком повседневности и государственной администрации Дубровника был итальянский.

11 Beritić 2000.

12 Stojan 1996, 2016; Shek Brnardić 2013: 212. 
В это же время накануне кризиса 1760-х годов изменился политический контекст, что было связано с внесением поправок в избирательный закон ${ }^{13}$ и соперничеством двух партий в правящих кругах ${ }^{14}$. Многие аристократы были вынуждены пересмотреть свое видение патриотизма, сообразуясь с духом Просвещения. Это выразилось в стремлении к реформированию существующего порядка и внедрению полезных знаний и прогрессивных достижений в повседневную жизнь ${ }^{15}$. По словам итальянского историка Франко Вентури (19141994), союз (дословно «брак») патриотизма и космополитизма стал главной характеристикой европейского Просвещения ${ }^{16}$.

В этом контексте я рассматриваю инициативу по созданию и недолгую деятельность Патриотического общества ${ }^{17}$, основанного аристократом, литератом и меценатом Михо Сорго (Соркочевичем, 1739-1796), «одним из круга самых грамотных людей, ценителем искусства и литературы» ${ }^{18}$, «обладателем тонкого вкуса» ${ }^{19}$. В статье исследованы процесс основания и цели Патриотического общества, деятельность его членов, темы сохранившихся выступлений.

13 Lonza 2000.

14 «Саламанкцы» были представителями старой аристократии, а «сорбонцы»новой, сформировавшейся после землетрясения 1667 г. Подробнее см.: Muljačić 1959b, 1959c. О разногласиях в среде дубровницкой аристократии было известно Вольтеру: «Хотите получить удовольствие и подробно рассмотреть все правительства на земле, начиная от китайского императора Хиао и еврейской орды и кончая последними распрями в Рагузе и в Женеве?». Цит. по: Вольтер. Разговор между А, В и С // Избранные произведения / сост. и ред. Е. Книпович, Б. Песиса. М.: ОГИЗ Государственное издательство художественной литературы, 1947. С. 477.

${ }^{15}$ Появилась немыслимая ранее идея о переустройстве политической системы Дубровника с заменой наследственной аристократии выборной, за что выступил Томо Басельи. См.: Muljačić 1995: 76.

${ }_{16}$ Shek Brnardić 2004: 12-13.

17 Поскольку Патриотическое общество было частным, а не публичным учреждением, не сохранилось его архива. О существовании этого по сути клуба свидетельствуют отдельные упоминания в биографиях, переписке и рукописях, сохранившихся в семейных архивах членов общества, которые были случайно найдены исследователями. См.: Maixner 1952; Muljačić 1959a. На эти издания ссылается большинство специалистов. Анализ выступления о воспитании аристократов дан в: Seferović 2015.

${ }^{18}$ Appendini F.M. De vita et scriptis Junii Antonii filii comitis de Restiis patricii Ragusini commentariolum // Appendini F. M. Junii Antonii comitis de Restiis patricii Ragusini carmina. Padova: typis seminarii, 1816. P. ix.

${ }^{19}$ Appendini F.M. De vita et scriptis Bernardi Zamagnae patricii Rhacusini. Zadar: Ivan Demarchi, 1830. P. 54. Аппендини утверждал, что Сорго читал древнегреческую и латинскую поэзию в оригинале. 
Особое внимание уделено проблеме учреждения научных кружков, которые представлялись движущей силой реформирования старой республики и осуществления просветительского проекта в маленьком адриатическом государстве. В качестве диахронического введения приведен краткий экскурс в историю академического сообщества Дубровника в эпоху Возрождения и барокко, определены его интересы и занятия, которые имели мало общего с просветительской деятельностью.

\section{Дубровницкие академии: от «otium» к «negotium»}

В соответствии с гуманистической философией дубровницкая интеллектуальная и политическая элита еще в эпоху Ренессанса разделяла рабочее и нерабочее время, то есть профессиональную деятельность (лат. negotium) и досуг (лат. otium) ${ }^{20}$. Эта дихотомия созидания, известная еще с античности, была разработана философами-гуманистами и принята дубровницкой аристократией. Otium подразумевал отдых от основного занятия, время, которое человек мог посвятить литературной деятельности (лат. litterae), то есть себе и своим литературным и научным интересам, удовлетворению духовных потребностей. Пребывая в «Аркадиях» - загородных виллах, например, в Трстено или Дубровницкой Риеке, любители все же не предавались творчеству в одиночестве, напротив, они находились в поисках единомышленников, которые необязательно должны были быть знатного происхождения. В отличие от профессиональной деятельности, общение на досуге подразумевало тесные контакты аристократов и простолюдинов, увлекавшихся стихосложением, языкознанием и вопросами, относящимися к общей эрудиции, как это предполагалось в «Республике ученых» (Res publica litteraria) ${ }^{21}$.

Первая такая «Академия согласных» (Accademia degli Concordi), в силу тяготения к романскому искусству и верности традициям

20 Латинским термином «otium» обозначался отдых или досуг, в то время как дословный перевод negotium - это «отсутствие досуга», то есть «деятельность», «обязанность», «работа». В Древнем Риме, наследие которого пристально изучалось гуманистами, дихотомия базировалась на контрасте между «личным временем и публичной политической деятельностью (в трудах Цицерона, Саллюстия, Плиния Младшего и др.). См.: Stolz 2018: 81-82.

${ }^{21}$ Janeković Römer 2004. 
Римско-католической церкви поддерживавшая тесные связи с Италией, была основана по «образцу» итальянских ренессансных обществ. Инициаторами ее создания во второй половине XVI в. были дубровницкий аристократ Савино де Бобали Сордо (1530-1585) и Михо Мональди (1540-1592). В этот кружок входили приятели Бобали, которые увлекались поэзией не на латинском, а на итальянском языке в духе гуманизма Петрарки ${ }^{22}$. О деятельности академии практически ничего не известно, предположительно местом собрания служил зал над помещениями таможни во дворце Спонца.

В конце XVII в. в Дубровнике, едва оправившемся после землетрясения 1667 г., местные поэты и литераты объединились в «Академии эрудитов-бездельников» (лат. Academia otiosorum eruditorium, итал. Accademia degli Oziosi Eruditi), подражавшей знаменитой Academia degli Arcadi, основанной в Риме в 1690 г. Итальянская «Аркадия» ставила целью возвращение к простоте стихосложения, отказ от барочного украшательства и напыщенности и формирование обновленного литературного вкуса. Вдохновением для деятелей общества служила античная Аркадия, безмятежный край пастухов на полуострове Пелопоннес, увековеченный в «Буколиках» («Пастушьих песнях») Вергилия ${ }^{23}$. Римская академия «Аркадия» стала модной и влиятельной как во многих городах Италии, так и на другом берегу Адриатики. «Аркадская поэзия» глубоко внедрилась в образ жизни общественной и интеллектуальной элиты как в приморских, так и континентальных областях Хорватии, поскольку внесла существенное оживление в классическое гуманистическое воспитание, предлагаемое иезуитскими коллегиумами.

Дубровницкая «Академия эрудитов-бездельников» объединила знать и простолюдинов, молодежь и пожилых людей, дубровчан и итальянцев, торговцев и священников. По мнению М. Деяновича, в академии преобладало консервативное мировоззрение, характерное для аристократов (из домов Сорго, Бона и т.д.) и монахов (бенедиктинцев и иезуитов), которые составляли большинство среди «академиков» ${ }^{24}$. Их деятельность не была непрерывной, напротив, на протяжении 40 лет (1690-1730) общество не раз приостанавливало работу

\footnotetext{
${ }^{22}$ Bogišić 1986: 67.

${ }^{23}$ Deanović 1933: 4-5.

${ }^{24}$ Deanović 1933: 55.
} 
в связи с неблагоприятными обстоятельствами, а затем возобновляло деятельность ${ }^{25}$. Главным интересом номинально являлась литература, развитие которой было основной целью энтузиастов. В их планы входило создание латинско-итальянско-хорватского словаря, но, к сожалению, этот проект не был осуществлен. Достижения «Академии» - публичного учреждения ${ }^{26}$, чей авторитет признавали власти Дубровника (но не оказывали финансовой поддержки), не имели существенного значения.

В эпоху Просвещения, когда приоритетом были «всеобщее благо» и рационализм ${ }^{27}$, деятельность литературных академий, не приносящая практической пользы обществу, подверглась критике. Например, уже упомянутый Альберто Фортис раскритиковал первое издание открытой в Дубровнике типографии ${ }^{28}$. Карло Антон Оччи в 1783 г. в рамках публикации произведений «иллирских» ${ }^{29}$ поэтов XV-XVIII вв. издал стихотворения на итальянском языке «академиков» из ренессансного кружка Савино де Бобали и Михо Мональди ${ }^{30}$. Рецензент указал, что большинство сонетов скучные и посредственные:

[Д]ля дубровницких умов выгода от новой типографии будет очевидной, если печатники познакомят общественность со свершениями нынешнего столетия - с работами Стая, Кунича и Бошковича, которые сейчас делают честь Отечеству, и воскресят «[Академию] Согласных» (Accademia di Concordi) ${ }^{31}$, которая будет заниматься

25 Deanović 1933: 42.

${ }^{26}$ «Академия» называлась публичной (pubblica) в отличие от существовавших частных (particolare). Ibid. 46.

27 Shek Brnardić 2013: 195.

${ }^{28}$ Muljačić 1952: 84; Muljačić 2011: 10; Malinar 2018: 106. Анонимную рецензию см.: Nuovo giornale enciclopedico. 1784: 16-20. № 1.

${ }^{29}$ В первую очередь дубровницких, хотя «иллирским» в этом контексте назван южнославянский язык, дубровницкий диалект которого считался совершенным благодаря развитию литературы в целом.

${ }^{30}$ Rime del N. U.S. Savino de Bobali Sordo, e del Sig. Michele Monaldi; dedicate all'Eccelso Senato di Ragusa. Dubrovnik: Carlo Occhi, 1783.

31 Фортис имел в виду «Академию согласных» в Ровиго - ренессансное общество, которое в XVIII в. получило покровительство венецианского Сената (в последствие имело поддержку на государственном уровне) и в основном занималось вопросами применения научных знаний на практике, например, в сельском хозяйстве. См.: Biscaccia 1846: 20. 
полезными точными науками, вместо «Академии бездельников» (Accademia degli Oziosi) с ее петраркизмом ${ }^{32}$.

Собственно говоря, Альберто Фортис был вдохновителем создания дубровницкого Патриотического общества, так как подал эту идею в опубликованных письмах, адресованных молодому и одаренному аристократу Томо Басельи (Басилевичу, 1756-1806). Родители Томо Якобица и Ката Басельи, урожденная Сорго, и брат матери Михо Сорго отправили его изучать право не в Италию, что было обычной практикой, а в республиканскую Швейцарию, точнее, в протестантский Берн ${ }^{33}$. Находясь недалеко от Германии, он воспользовался возможностью и продолжил обучение в Геттингенском университете, а после переехал в Вену, где женился на Марии (Мими) фон Борн, дочери известного минералога масона Игнаца фон Борна (1742-1791) ${ }^{34}$. В глазах дубровчан такое «большое путешествие» (grand tour) выглядело весьма оригинальным, но тем не менее послужило приобщению молодого человека к достижениям центральноевропейской науки, с которыми он впоследствии должен был познакомить соотечественников. Хотя из переписки Михо Сорго и Томо Басельи следует, что дядя намекал племяннику на создание в Дубровнике просветительского кружка еще в 1785 г., эта идея получила воплощение только в 1793 г. по возвращении последнего из-за границы. К сожалению, в отличие от «Академии бездельников» активная работа нового общества продлилась всего один год.

\section{Учреждение и члены Патриотического общества}

По Вашем приезде я хочу собрать немного книг и пригласить несколько человек, чтобы мы могли общаться и хотя бы на уровне идей коммуницировать с остальной культурной Европой. Мы несчастны в своем стремлении к знаниям, которые сейчас есть нечто отталкивающее, к чему относятся с пренебрежением ${ }^{35}$.

32 Речь идет об имитации поэтического стиля Франческо Петрарки. В эпоху Просвещения и динамичного развития бесцельный досуг считался пороком; например, Руджер Бошкович писал брату: ЊБезделие - худшая вещь». См.: Stojan 2018.

33 Друг семьи Руджер Бошкович предлагал отправить Басельи на учебу в католический Фрибур.

34 По возвращении в Дубровник Басельи столкнулся с рядом проблем из-за брака. См.: Franić Tomić 2018.

${ }^{35}$ Михо Сорго - Томо Басельи, 21 мая 1785 г., см.: DAD. Arhiv obitelj BassegliGozze. Kut.12. Omot C2/10. Цит. по: Muljačić 1959a: 321. 
Первые сведения о том, что Михо Сорго учредил Патриотическое общество, предоставил в 1834 г. поэт и комедиограф Влахо Стулли (Стулич, 1768-1843), который был хорошо знаком с Сорго и написал его первую биографию ${ }^{36}$. По его мнению, Сорго основал «академию», чтобы найти способ «веселее проводить дни» ${ }^{37}$, омраченные болезнью. С этой целью он объединил «особенно дорогих ему друзей и грамотных людей», способных поэзией и прозой облегчить его вызванные недугом страдания ${ }^{38}$. Состояние Михо Сорго усугубилось из-за «горечи» утрат в «личной и публичной жизни» ${ }^{39}$. Помимо неудач на политическом поприще, серьезный удар по его здоровью нанесло самоубийство брата Луки, который выбросился из окна третьего этажа фамильного особняка 11 сентября 1789 г. Забота о вдове покойного, осиротевших четырех дочерях и сыне Антуне легла на плечи Михо. Вероятно, встречи участников кружка происходили в «великолепной библиотеке» во дворце Сорго ${ }^{40}$ на Пустиерне (ныне Епископский дворец), который еще тогда был известен богатым убранством ${ }^{41}$. Была в этом и заслуга Михо, который, обосновавшись в Дубровнике после многолетних путешествий по Италии, личных и дипломатических, приказал украсить стены дома портретами дубровчан, прославившихся в области науки

36 Stulli 1834. Подобная инициатива не была новой для семейства Сорго, поскольку и ранее в их городском особняке и на загородных виллах были рады ученым людям, начиная с деда Михо Сорго Луки Соркочевича, принимавшего у себя членов «Академии бездельников», в которой он состоял вместе с сыновьями Михо и Антуном. См.: Dejanović 1933: 45-46. Также в Мокошице в доме их родственника Марина ОрастовСорго в 1743 г. гостил Руджер Бошкович. В обществе Сорго и других аристократов, любительски изучавших физику и математику, он представил свою оригинальную атомистическую теорию. См.: Stojan 2018. Такие приватные встречи вызвали подозрение у представителей католической церкви, поэтому были в донесении в Ватикан представлены как запрещенные масонские собрания. См.: Кovač 1913: 56-57. Об истории семьи Сорго см.: Ć́osić, Vekarić 2005: 204-211.

37 Первые заседания Патриотического общества, скорее всего, состоялись в феврале 1793 г., так как в одном из первых докладов упоминалась недавняя кончина ученого Франьо Стая 10 февраля 1793 г.

38 Stulli 1834. Об инициативе Михо Сорго упоминалось и на первой странице «Загребской речи» о научных обществах, вероятно принадлежащая перу Антуна Казначича, в архиве которого и найдена рукопись.

39 Chersa 1824: 37.

40 Холостяк Сорго (согласно Стулли, он не женился из-за любви к науке) жил тогда с братом Лукой, его женой и детьми.

${ }^{41}$ Novak 1978: 145. 
и искусства ${ }^{42}$. В его идее не было ничего удивительного, потому что Михо и его брат Лука были дипломатами ${ }^{43}$ и космополитами, обладавшими широкими связями с итальянской и австрийской элитами. В Дубровнике они собирали вокруг себя родственников и друзей из аристократической среды со схожими увлечениями и открытостью к новым веяниям ${ }^{44}$.

Михо Сорго состоял в римской «Аркадии», был член-корреспондентом падуанской Академии наук (Accademia delle scienze) ${ }^{45}$, во время путешествий его радушно принимали в известных итальянских литературных салонах. Его друг и почитатель Фортис отметил, что Сорго был весьма приятным человеком и во всех итальянских городах, которые посетил, оставил о себе исключительно хорошее впечатление в обществе. Образованный, красноречивый, темпераментный, он вызывал у собеседников восторженные впечатления. Из-за присущей ему скромности мало кому было известно, что он «с удовольствием пишет иллирские стихи, приятельствует с итальянскими музами и обладает глубокими знаниями латинской поэзии, но эти занятия не отвлекают его от государственных забот и серьезной науки» ${ }^{46}$. Действительно, Сорго в первую очередь привлекала «родная старина» (gran genio per le antichità), помимо издания книг по истории, он интересовался и вопросами «иллирского» то есть славянского языка ${ }^{47}$, занимался археологическими раскопками Эпидавра ${ }^{48}$, ставил перед собой задачу создания справочника дубровницкого

42 Muljačić 1959a: 322. О картинах см.: Prijatelj 1996.

43 Лука Сорго был послом Дубровника в Вене в конце 1780 - начале 1781 г., в первые годы правления императора Иосифа II. C того времени сохранился его дневник на итальянском языке, перевод которого на хорватский в данный момент готовится К. Радош-Перкович к публикации в рамках проекта Netmus 19 - Networking through music: changes of paradigms in the "long" nineteenth century from Luka Sorkočević to Franjo Ks. Kuhač («Netmus 19 - социальные связи через музыку: изменения парадигм в «долгом» XIX в. от Луки Соркочевича до Франьо Кс. Кухача») под руководством В. Каталинич.

${ }^{44}$ Stojan 1996; 2016.

45 Muljačić 2011; Muljačić 1979: 246.

46 Письмо Альберто Фортиса Елизавете Каминер Турра опубликовано как «Lettera del Sig. Alberto Fortis alla Compilatrice del Giornale» в: Nuovo Giornale Enciclopedico. 1781: 33-41. № 3. См.: Muljačić 1968: 40-42.

47 Rezar 2000.

48 Эпидавр - греческое и римское поселение на месте современного г. Цавтат в Хорватии (прим. перев.). Appendini F.M. Notizie istoricho-critiche sulle antichitá, storia e letteratura de' Ragusei. Ragusa: Dalle stampe di A. Martecchini, 1802. P. 44-45, 49. 
права ${ }^{49}$. Также он в духе Просвещения способствовал прославлению выдающихся соотечественников и с этой целью опубликовал панегирики ученым Франьо Стаю и Раймунду Куничу, а Руджер Бошкович завещал ему свои рукописи ${ }^{50}$.

Замыслы Сорго о создании научного общества были тесно связаны с его племянником Томо Басельи. После распада несчастливого брака он вернулся в Дубровник летом 1792 г. и по окончании траура по умершему единственному сыну вернулся к общественной службе, а также стал помогать дяде в организации кружка «патриотическо-благотворительного типа» (patriotisch-gemeinnützig), какие он видел ранее в Швейцарии и Германии. Еще Альберто Фортис, который был координатором обучения Басельи в Швейцарии, а именно в протестантском Берне, где у него были необходимые связи ${ }^{51}$, предполагал, что тот сыграет роль главного реформатора по возвращении на родину. Помимо сообщения об открытии новых минералов в Калабрии в путевом письме от 30 октября 1783 г. Фортис ознакомил своего протеже с планом преобразований, который позднее был издан по-немецки, потому что итальянская цензура из-за критики католической церкви не допустила бы публикации текста ${ }^{52}$. В письме особенно подчеркивалась необходимость учреждения в Дубровнике научного общества: «Сейчас в городе не хватает полезной и патриотической академии наук, которая могла бы стать главным образовательным центром всей нации». Важным было замечание, что в прошлом уже существовали «академии», занимавшиеся стихосложением, а сейчас нужно «собрать общество, достойное нашего столетия», которое могло бы обсуждать серьезные вопросы, то есть искусство, торговлю и историю Дубровника ${ }^{53}$.

49 Muljačić 1952: 100. Наличие таких интересов у Сорго опровергает сложившееся в историографии мнение, что Сорго был всего лишь «затейник, бонвиван и “аркадянин”, для которого занятия литературой были забавой». Ср.: «Больше острослов, чем писатель, Михо Сорго и “академию” считал больше развлечением, чем серьезной работой». См.: Maixner 1952: 60.

50 Sorgo M. Elogio dell'Abate Francesco Stay. Dubrovnik: Carlo Occhi, 1793; 1795. Stulli 1834: 416-417.

51 Muljačić 1958: 10.

52 Часть письма Фортис ранее разрешил опубликовать в оригинале в Неаполе. См.: Fortis A. Lettere geografico-fisiche sopra la Calabria, e la Puglia al conte Tommasso de Bassegli patrizio Raguseo. Napulj: Giuseppe-Maria Porcelli, 1784.

${ }^{53}$ Fortis A. Mineralogische Reisen durch Calabrien und Apulien von Alberto Fortis // Briefen an den Grafen Thomas von Bassegli in Ragusa. Weimar: in der Hoffmanischen Buchhandlung, 1788. S. 28-29. 
В записках Басельи отражены его собственные мысли о патриотическом обществе. Помимо мечтаний о реформах в Дубровницкой республике, увлеченный естественными науками, физикой, химией и математикой, он вспоминал немецкие и швейцарские кружки, на которые действительно стоило бы ориентироваться, и предполагал открыть еще небольшую библиотеку, естественнонаучный музей и физическую лабораторию. Таким образом, одно общество способствовало бы развитию «светского образования и культуры нации». Из этого следует, что они с Сорго всерьез задумывались о формальном основании кружка, но именно Басельи планировал через знакомых добыть уставы академических обществ в Бремене и Берне, с деятельностью которых он лично ознакомился ${ }^{54}$. У него был опыт исследовательской работы в естественнонаучной области - в 1783 г. он недолго состоял в Физическом обществе Лозанны (La société des sciences physiques de Lausanne $)^{55}$. В следующем году он стал почетным членом Экономического общества в Берне (La société de économique de Berne) ${ }^{56}$. В Базеле Басельи был принят в масонскую ложу «К настоящей дружбе» (Zur vollkommen Freundschaft), а в августе 1785 г. в Вене присоединился к ложе своего тестя Игнаца фон Борна «К истинной гармонии» (Zur wahren Eintracht $)^{57}$. Конечно, официально об этом в Дубровнике никто не знал, но тем не менее в городе ходили слухи.

Швейцария в то время отличалась многочисленностью просветительских обществ, возникавших в основном по инициативе патриотов (в одном только Базеле существовало около 13 таких организаций $)^{58}$, и произвела на Басельи такое впечатление, что он называл эту страну своей второй родиной ${ }^{59}$. Объединение в клубы и кружки по интересам он считал полезным, потому что они сближали и облагораживали

54 «Общество людей, которое организует для своих нужд небольшую библиотеку, музей естественной истории, физическую лабораторию, существенно повлияет на формирование основ светского образования и культуры нации. Я хотел бы ознакомиться со статутами этих обществ, которыми можно было бы воспользоваться в дальнейшем. Майнерс обещал их достать. Устав Музыкального дома в Берне я получил от W» (вероятно, Wyttenbach. - Т. ШІ.-Б.). См.: Muljačić 1998.

55 Muljačić 1998: 243.

56 Muljačić 1955: 57.

57 Irmen 1994: 343.

58 Im Hof 1981: 9.

59 Письмо Томо Басельи сестре Деше от 1 октября 1783 г., цит. по: Verecchia 1975: 132. Оригинал хранится в фонде Басельи - Гоцце в Государственном архиве Дубровника. 
людей, давали им возможность обмениваться идеями и чувствами ${ }^{60}$. Патриотическое общество как средство просвещения занимало важное место в планах Басельи по реформированию Дубровницкой республики ${ }^{61}$ :

Цель патриотического общества в неустанной работе для общего блага: борьба с предрассудками, просвещение нации, забота о ее насущных интересах, о расширении кругозора, распространении грамотности, образовании клира, который должен совершенствовать связи между религиозной философией и гражданскими законами. Все это происходит постепенно; время, которое все разрушает, так же все обновляет и восстанавливает $<\ldots>$ И, хотя я не стану свидетелем пользы, какая исходит от обществ, каким должно быть наше, я искренне желаю, чтобы однажды в лучшие времена оно достигло успеха. Благодаря культурности и просвещенности мы с каждым днем [все] больше становимся людьми <..> Но устремлениям разумных еще долгое время будут угрожать объединившиеся силы дураков и сумасшедших, так как для этих пород [людей] важно, чтобы все оставалось по-старому ${ }^{62}$.

Необходимо также упомянуть, что сторонником идеи об основании общества был и просвещенный священник Джуро Ферич (17391820), ученый, баснописец и поэт незнатного происхождения, который собирал и переписывал произведения дубровницкой литературы на славянском языке. Он был домашним учителем Томо Басельи и многих других молодых аристократов, дружил с Михо Сорго и помогал ему с публикацией в 1790 г. исторического труда Людовика Цриевича Туберона «Записки о моем времени» ${ }^{63}$. Ферич, как и Сорго, был членом римской «Аркадии» и еще нескольких итальянских «академий». Его биограф, дубровницкий литератор и дипломат Томо Крша (1782-1826), ссылаясь на некоего итальянского писателя, отметил, что Ферич находил литературные собрания весьма полезными, потому что они побуждали людей восхвалять и имитировать добродетельную жизнь. Именно он предложил Михо Сорго устраивать

${ }^{60}$ Рукопись Т. Басельи «Clubs, assembles, sociétés» см.: DAD. Arhiv Bassegli-Gozze. Kut. 5. B2/7.

61 Подробнее см.: Shek Brnardić 2006.

${ }^{62}$ Рукопись Т. Басельи «Plan de réforme de la République de Raguse» цит. по: Muljačić 1958: 33.

63 Rezar 2000. 
в его доме встречи немногочисленных почитателей науки (lettere), чтобы они могли свободно говорить на любые научные темы и о литературе и наслаждаться общением. Крша подчеркивал, что Сорго удовлетворил просьбу своего друга и приглашал дубровчан, «которые искали почет и славу делами разума». Считается, что на первых собраниях Ферич декламировал свои басни ${ }^{64}$. Крша, который из первых уст, от Ферича, мог узнать все подробности о деятельности «академии» Сорго, зафиксировал причины ее роспуска:

Эта академия, хотя и была приватной, но предвосхитила рост научных исследований (incremento degli studi) в Дубровнике и была распущена буквально сразу же после основания по вине завистливых невежд, которые в противовес знаниям (lettere) свою безграмотность выставили достоинством ${ }^{65}$.

В обществе Сорго состояли как аристократы, так и простолюдины. Такое социальное смешение - нехарактерное для дубровницкой элиты - объяснялось просветительскими постулатами, согласно которым личные заслуги ценились больше, чем знатное происхождение. Меритократия была обычным явлением в общественных институтах и научных и творческих кружках, в рамках которых источником престижа были знание и мастерство, а не родовитость. К Патриотическому обществу примкнул аристократ, писавший на латыни сатирик, полиглот и юрист, политический единомышленник и друг Михо Сорго Юний Рести (Джоно Растич, 1755-1814) ${ }^{66}$. Будучи противником французской философии и новаторства, он все-таки присоединился к движению, формировавшемуся в окружении Сорго и Басельи, которое выступало за просвещение и мирное реформирование Дубровницкой республики. Об участии Рести в деятельности Патриотического общества писал пиарист, профессор риторики в дубровницкой гимназии итальянец Франческо Мария Аппендини (1768-1837), который вспоминал, как они с Рести (illum adiremus) «в определенные

${ }^{64}$ Chersa 1824: 37-38. В 1794 г. Ферич опубликовал книгу «Басни, родившиеся из иллирских пословиц» (Ferrich $G$. Fabulae ab Illyricis adagiis desumptae. Dubrovnik: Andrea Trevisani, 1794) - сборник латинских басен, которые происходили от народных пословиц. Ферич уделял особое внимание творческой составляющей дидактической литературы. См.: Pederin 1983: 228.

65 Chersa 1824: 38.

${ }^{66}$ Подробнее о Рести см.: Janeković 2013. 
дни три раза в месяц» бывали у Сорго, пока тот был еще жив. Рести выступил с речью «О патриотизме» на итальянском языке, в которой он «отождествил возвышенность темы с чистотой и элегантностью итальянского языка, кроме того продемонстрировал, с какой любовью и преданностью заботится о родине и старается противостоять злу и трудностям в Республике» ${ }^{67}$.

Источники свидетельствуют, что кроме Рести и Аппендини к этому объединению также были причастны служивший в Дубровнике итальянский хирург Микеланджело Роини, протеже братьев Сорго, талантливый студент-медик из Болонского университета Лука Стулли, а его брат Влахо, биограф Сорго, вероятнее всего, был членом Патриотического общества ${ }^{68}$. Томо Басельи пригласил в качестве члена-корреспондента ученого из Вены Степана Райчевича, которого он и Ферич хорошо знали. Тот представил свое исследование о торговле пшеницей, поскольку, будучи австрийским дипломатом, много об этом знал ${ }^{69}$. Михо Сорго пытался привлечь и сплитского врача Юлия Баямонти. На одном из заседаний его трактат о плагиате в исследованиях по физиологии для присутствующих зачитал Роини. В письме Баямонти от 4 марта 1794 г. Сорго в последний раз упомянул об обществе ${ }^{70}$. Итак, в доме Сорго собирались дубровчане, аристократы и простолюдины, которые позднее играли важную роль в социальной и культурной жизни города. Тематика их бесед была разнообразной, но в основном связанной с судьбой родины - Дубровницкой республики. На каждой встрече кто-то из членов общества представлял научное исследование, а остальные участвовали в обсуждении ${ }^{71}$, на основании их точек зрения формировалось общее мнение.

${ }^{67}$ Appendini F.M. De vita et scriptis Junii Antonii. P. IX.

68 Влахо Стулли прямо упомянул о том, что Михо Сорго «любезным письмом пригласил его брата в свою “академию”, когда тот уже уехал учиться в Болонью». См.: Stulli 1834: 417.

${ }^{69}$ Письмо, вероятно, написано в марте 1793 г., см.: DAD. Arhiv Bassegli-Gozze. C2/11, без даты. Цит. по: Muljačić 1959a: 330.

70 Археологический музей Сплита, 49 h 1². Цит. по: Muljačić 1959: 330. Как считает Йосип Берса, членство Альберто Фортиса, Франьо Стая, Марина Мартеллини и Брно Заманьи в обществе Михо Сорго не подтверждено источниками, однако не стоит исключать такую возможность. См.: Bersa 2002: 168. Также в обществе могли состоять племянник Михо Антун Сорго и его друг Марко Бруревич (Марк Брюэр Дезриво), сын французского консула в Дубровнике.

${ }_{71}$ Михо Сорго - Юлию Баямонти, 4 марта 1794 г. Цит. по: Muljačić 1959a: 330. 


\section{Речи - призывы к реформированию Дубровницкой республики}

Какие аспекты патриотизма интересовали сторонников Сорго? В чем заключалось его понимание патриотизма? Историк Рихард ван Дюльмен определил как «патриотические» те общества, которые «осуществляют деятельность из целесообразности в силу патриотических и нравственных интересов, ориентированных на выработку не столько научных, сколько практических знаний, которые можно было бы распространять и применять в повседневной жизни социума» ${ }^{72}$. Идея патриотизма как добродетели была связана с философией Просвещения, поэтому патриоты считались наиболее просвещенной частью общества ${ }^{73}$. Ключевыми словами в лексиконе нового патриотизма стали понятия «всеобщее счастье», «польза для общества» и «общественное благо» ${ }^{74}$. Деятельность просвещенных патриотов была так или иначе связана со счастьем/благодеяниями, то есть с улучшением качества жизни сообщества, в связи с чем и формировались различные патриотические и благотворительные организации, объединявшие представителей разных слоев населения.

Важно также отметить, что название дубровницкого Патриотического общества было переводом с французского языка выражения из речей Томо Басельи. Два сохранившихся текста на французском начинаются с упоминания Патриотического общества (la société patriotique): «Господа, Патриотическое общество, подобное тому, что вы учредили, одним своим названием, а в большей степени тем пылом, что вас побуждает к действию, провозглашает любовь к общественной пользе главной целью вашего объединения» ${ }^{75}$; «Друзья мои! Патриотическое общество, как мы его назвали, должно принимать в расчет исключительно общественную пользу и предполагаемое всеобщее благо для наших соотечественников» ${ }^{76}$. Как уже было сказано, опыт пребывания Басельи в Швейцарии дал ему возможность узнать, что есть «патриотический дух», формирующий общество, в котором он живет.

${ }^{72}$ Van Dülmen 1996: 67, 69.

73 Krauss 1967: 391.

74 Shek Brnardić 2010: 634.

75 Basiljević 2003: 260. Оригинал по-французски см.: Muljačić 1958: 62.

${ }^{76}$ Bassegli T. Des causes de la pauvreté et de la mendicité dans notre pays, et des moyens d' y remédier // Muljačić 1958: 103. 
В заметках о поездке по Европе либеральный публицист Карло Антонио Пилати (1733-1802), которого Басельи читал и цитировал, размышлял:

Во всех кантонах встречаются достойные мужи - республиканцы, швейцарцы - единственная современная нация, пестующая добродетель, называемую любовью к родине, в то время как у других народов об этом даже мысли не возникает. Такие граждане в большом количестве проживают в Цюрихе, Берне и Базеле. Существуют такие общества, для которых нет иной цели, кроме как осчастливить своих сограждан и добиться процветания для всей конфедерации ${ }^{77}$.

Пилати отметил, что швейцарцы развивают многие направления научных знаний и среди них много ученых, которые обладают широкими возможностями в исследованиях, то есть могут заниматься тем, к чему имеют предрасположенность. Вместе с тем особенно подчеркивалось, что в своей деятельности они ориентируются на общее благо $^{78}$. Басельи, тайный масон ${ }^{79}$, предполагал, что именно общественная польза станет главной целью для Патриотического общества - эта идея должна была быть основополагающей в его программной речи.

В связи с тем, что общество не оставило архива, случайно время от времени обнаруживались тексты выступлений, которые предположительно заслушивались на заседаниях ${ }^{80}$. Сейчас исследователям известны восемь названий и рукописей на итальянском и французском языках:

1) «Академическая дискуссия. Об особенной пользе литературных обществ в малых республиках» (Discorso accademico. Della special utilità delle società) анонимного автора ${ }^{81}$;

77 [Pilati C.A.]. Voyages en différens pays de l'Europe en 1774, 75, 76. Vol. 1. La Haye: C. Plaat, 1777. P. 188.

78 Ibid. 189.

79 О масонстве Басельи кто-то донес, информация стала достоянием общественности. См.: Radoš 2016: 328.

80 Всего было проведено более десяти мероприятий, как отмечает неизвестный автор «Загребской речи», ссылаясь на письмо Михо Сорго Юлию Баямонти от 4 марта 1794 г., в котором упоминалось, что члены общества встречаются регулярно. Цит. по: Muljačić 1959a: 330.

81 Оригинальная рукопись, то есть конспект речи с множеством исправлений, хранится в Архиве Хорватской академии наук и искусств в Загребе, см.: Arhiv HAZU. Obitelj Kaznačić - Dubrovnik, 1764-1899. XV 21/B V 8. В 1952 г. ее опубликовал 
2) «Об образовании, которое должно быть у нашей аристократии в нынешних обстоятельствах» (Dell'educazione che conviene ai Nostri Nobili nelle presenti circostanze) анонимного автора ${ }^{82}$, датирована 16 марта 1793 г.;

3) «О патриотизме» (Discorso sul patriotismo) Юния Рести ${ }^{83}$, датирована 15 июня 1793 г.; принадлежала Томо Басельи;

4) «Об общественной пользе» (Discours sur l'utilité publique) $)^{84}$;

5 ) «О деньгах и чеканке монет» (Sur la monnoye et le monnoyage) ${ }^{85}$;

$6)$ «О причинах бедности и нищеты в нашей стране и способах исправления» (Des causes de la pauvreté et de la mendacité dans notre pays et des moyens d'y remédier $)^{86}$, неоконченная;

7) «Панегирик аббату Франьо Стаю» (Elogio dell'Abate Francesco Stay $)^{87}$ Михо Сорго, напечатана в Дубровнике в ноябре 1793 г.;

8) «Письмо доктора Юлия Баямонти преподобному Джамбаттисте да Сан-Марино, члену многих академий, о подлинных авторах некоторых открытий» Юлия Баямонти, которое зачитал Микеланджело Роини, опубликовано в Nuovo giornale enciclopedico («Новом энциклопедическом журнале») в январе 1793 г. ${ }^{88}$

Рудольф Майкснер (см. Maixner 1952). Жарко Мулячич обнаружил дубликат рукописи в собрании документов семьи Бонда в архиве Института хорватской истории в Дубровнике (см. Muljačić 1959a), на данный момент рукопись недоступна для исследователей.

82 Рукопись обнаружена Жарко Мулячичем в собрании документов семьи Бонда в архиве Института хорватской истории в Дубровнике (см.: Muljačić 1959a), на данный момент недоступна для исследователей. Некоторые ученые приписывают авторство Франческо Марии Аппендини, недолго проработавшему в Дубровнике; другие специалисты считают, что текст принадлежал Джуро Феричу, который был домашним учителем многих аристократов и три года преподавал в дубровницкой гимназии.

83 Рукопись долгое время считалась утраченной, пока я не обнаружила ее в архиве монастыря миноритов в Дубровнике: sig. 1144.

${ }^{84}$ DAD. Arhiv Bassegli-Gozze. Kut. 2. В2/7. Оригинал по-французски опубликован в: Muljačić 1958; по-хорватски см.: Kolo. 2003. № 4.

${ }^{85}$ DAD. Arhiv Bassegli-Gozze. Kut. 6. B2/12. В тексте Басельи раскритиковал отсталую систему выпуска денег - в Дубровнике монеты чеканили вручную молотом и не использовали пресс-машину, как в других странах. Muljačić 1958: 29, 53, 58.

${ }^{86}$ DAD. Arhiv Bassegli-Gozze. Kut. 6. B2/12. Оригинал по-французски опубликован в Muljačić 1958.

87 В начале текста указано «Речь была прочитана на одном из заседаний, которые еженедельно проходят в доме автора», то есть на одной из встреч членов Патриотического общества. См.: Sorgo M. Elogio dell'Abate Francesco Stay. P. 5.

${ }^{88}$ В письме от 29 апреля 1793 г. Роини сообщил Юлию Баямонти, что на одном из заседаний общества зачитал его «Письмо», опубликованное в венецианском журнале в феврале того же года. См.: Muljačić 1959a: 327. 
На первых заседаниях Джуро Ферич декламировал свои басни.

Члены Патриотического общества обсуждали различные темы научной и литературной направленности в зависимости от предпочтений ораторов. Два выступления можно считать программными речами, в которых определялись цели организации - «О пользе научных кружков в малых республиках» анонимного автора и «Об общественной пользе» Томо Басельи, рассмотревшего на теоретическом уровне идею общественной пользы, которая как главное достижение связана с филантропией. Речь Юния Рести о патриотизме по духу близка предыдущим, так как с точки зрения естественного права он доказывал легитимность и оправданность патриотического чувства. Доклады о воспитании молодых аристократов, об искоренении нищеты и чеканке монет содержали конкретные предложения по решению насущных проблем в Дубровницкой республике. Отдельного рассмотрения заслуживает текст выступления о научных обществах.

Речь об их пользе, вероятно, принадлежала молодому человеку, который на тот момент был младше остальных членов кружка ${ }^{89}$. В тексте были представлены политические, нравственные аспекты, а также оценены технические возможности для основания общества в небольшой республике наподобие Дубровницкой. По мнению оратора, каждая такая институция, основанная из добрых побуждений, занимающаяся благотворительностью и ставящая перед собой достойные цели, представляла ценность. Этим критериям соответствовали и объединения, появлявшиеся благодаря тяге к знаниям и стремившиеся к распространению в обществе достижений как отечественной, так и зарубежной науки. Говоря о политической стороне вопроса, автор подчеркнул, что Дубровник находится под управлением аристократии, а призванием каждого аристократа является забота о благе нации и государства. Вместе с тем к государственной деятельности можно привлекать и представителей других сословий, которые, проявляя свои таланты на службе и развиваясь, могли бы добиться признания. Аристократы, в свою очередь, должны четко представлять, в чем состоят интересы государства, оценивать препятствия на пути и средства достижения общественного счастья, а также

89 Вероятно, это был Влахо Стулли, которому на тот момент было 25 лет. Его младший брат Лука в это время находился в Болонье. 
обязаны изучать обычаи, природу и ресурсы своей страны. Чтобы успешно исполнять обязанности, им с самого начала карьеры необходимо научиться в свободное от службы время в неформальной обстановке делиться своими мыслями и идеями с другими. Маловероятно, что человек, который с молодости живет в свое удовольствие, сможет дорасти до влиятельного сенатора, способного к публичным выступлениям и дебатам.

Bce, кто состоял в научных кружках, заметили бы, что эти знания и навыки пригодились им в профессиональной деятельности, что каждый из них не взял бы слово перед аудиторией без тщательной подготовки, но быстро бы приучился говорить на «языке разума и истины». Тогда их подготовленные и весьма полезные речи составили бы своеобразный «банк знаний и мудрости, почти что коллективный разум», прикоснувшись к которому, любой извлек для себя пользу. Регулярная работа над текстами раскрепостила бы людей, развила их красноречие и облегчила общение на любую тему. Доказывая ценность научных знаний для политиков, автор в качестве примера привел римского гражданина, государственного деятеля, философа и великого оратора Марка Туллия Цицерона. Каждый день после обеда на вилле в Тускулуме он принимал гостей в галерее, называемой им «Академией». Содержание их бесед сохранилось для потомков в виде знаменитых «Тускуланских бесед».

Моральный аспект в речи представлен сопоставлением монархического и аристократического государственного управления. В первом случае сила и авторитет власти сосредоточены в руках одного человека, который сам по себе должен стремиться к просвещению и добродетели. Небольшой круг людей, то есть министров, может только интерпретировать волю государя и иногда что-то советовать. В республиках же все граждане должны быть грамотными и высоконравственными, потому что в большей или меньшей степени исполняют социальные функции. Это касается главным образом ограниченных в пространстве республик, таких как Дубровницкая. Для порядка в них необходима большая доза «толерантности и этичного поведения». Для их достижения нужно развивать литературу и науку, так как жизненный опыт показывает, что их «истинные почитатели отличаются приятным характером и гибкостью поведения, легко привыкают к совместной жизни с другими людьми и стараются беречь мир». Далее оратор раскрыл образ «настоящего литерата» 
или «настоящего философа», который не завидует знаниям других и охотно делится своими. В этом контексте он упомянул о недавней кончине Франьо Стая, который был «совершенным образцом для подражания и другом литературы», а кроме того, выделялся среди других «толерантностью», поскольку умел соглашаться с людьми, имевшими диаметрально противоположное мнение ${ }^{90}$.

Выступавший кратко затронул вопрос о технических возможностях основания научного общества в Дубровнике, посетовав на изолированность города, который вынужден пользоваться только своими ресурсами и рассчитывать на таланты местных жителей:

Куда мы ни взглянем, увидим каменистую почву, мало обрабатываемую или вообще заброшенную землю, увидим окружающие нас варварские народы и бушующее море, которое отделяет нас от цивилизованных стран. Поэтому весь потенциал заложен в нас самих. Чем меньше у нас новых навыков и знаний, тем больше нам предстоит сделать для прогресса. Земледелие, торговля, мореплавание у нас на том уровне, на каком у других народов было столетия назад <..> Но если пестовать народный талант, то во всех этих направлениях можно весьма преуспеть ${ }^{91}$.

В завершение речи оратор призвал собравшихся быть последовательными и применять индивидуальный подход к достижению общего блага и просвещения, ведь если каждый постарается развивать свои способности и приумножать коллективные знания, то, таким образом, поспособствует их распространению и станет примером для других, а личные заслуги каждого станут лептой, отданной во славу Отечества. В продвижении этой практики главную роль могли бы сыграть научные общества. В конце автор предупредил противников этой идеи, «злых бездельников-невежд», способных очернить заслуги этих институций своими насмешками, что они получат достойный отпор 92 .

\section{Заключение}

Несмотря на планы основателей Патриотического общества изменить в лучшую сторону то положение, в котором оказался Дубровник,

\footnotetext{
90 Maixner 1952: 66.

91 Maixner 1952: 67.

92 Maixner 1952: 67.
} 
их объединение просуществовало недолго. На первой странице «Загребской речи» аноним оставил комментарий, что эта «академия» после десяти заседаний была обречена прекратить свою деятельность в силу обстоятельств «порочного времени, которое сумело очернить и осудить добрые начинания, а достижения организации поставить под сомнение» ${ }^{93}$. В последний раз общество упоминалось в письме Михо Сорго Юлию Баямонти от 4 марта 1794 г., и, как считал Жарко Мулячич, роспуск был санкционирован Большим советом, который назначил всех членов кружка, кроме Сорго и Басельи, на административные должности за пределами Дубровника, чтобы помешать им регулярно встречаться ${ }^{94}$.

Важно отметить, что в центральноевропейских государствах, в частности, в Швейцарии и Германии, подобные объединения старались применять достижения современной науки на практике и были подспорьем для государства ${ }^{95}$. В Дубровнике, напротив, такая частная инициатива была воспринята как оппозиция ${ }^{96}$ существующей власти, особенно после Великой французской революции. Два года спустя после роспуска Патриотического общества в мятежном Париже на руках Альберто Фортиса скончался его разбитый инсультом основатель Михо Сорго, начинания которого канули в небытие ${ }^{97}$.

Томо Басельи, вернувшийся из-за границы и имевший целью распространение идеалов Просвещения, был на особом счету у консервативных кругов, не принимавших его новаторства, подразумевавшего радикальные перемены в политической жизни республики. В уединении он мечтал о проведении реформ в Дубровнике и планировал мероприятия, о чем свидетельствуют его рукописи ${ }^{98}$. Кроме все-

93 Maixner 1952: 62.

94 Muljačić 1959a: 329-330.

95 Van Dülmen 1996: 67.

96 Banac 1996: 64.

97 Не прибегая к глубокому анализу политической ситуации в Дубровнике, можно сделать вывод, что имело место противостояние двух типов патриотизма - современного просветительского и старого аристократического. О партиях в дубровницких аристократических кругах подробнее см.: Muljačić 1959a, Muljačić 1959b; о патриотизме аристократии см.: Č́osić, Vekarić 2005. Вопросу о консерватизме и традиционализме в дубровницкой политической культуре посвящена работа Л. Кунчевича: Kunčević 2020. История политической мысли в Дубровнике заслуживает отдельного рассмотрения в будущих исследованиях.

98 Рукописи Томо Басельи хранятся в папках, подписанных неизвестной рукой «План реформ в республике Рагузы, разработанный господином Томасом де Басельи, 
го прочего, он размышлял о введении выборного управления взамен аристократического с присвоением дворянского титула заслуженным деятелям, а также о создании под протекторатом Франции «Иллирской республики», в состав которой вошли бы Хорватия, Славония, Сербия, Босния и Далмация с Дубровником. ${ }^{99}$ Однако Басельи не был революционером «французской» закалки, его версия модерного просвещенного патриотизма была сопряжена с мирными преобразованиями и качественными изменениями, в этом смысле он был противником так называемой «философской революции» ${ }^{100}$. Просвещенный мир все время трансформировался, поэтому франкофилы, и Басельи в их числе, надежды на перемены связывали с вторжением войск Наполеона в мае 1806 г. Но в результате долгожданных перемен в 1808 г. Дубровник безвозвратно утратил республиканский строй.

Перевод с хорватского Л.К. Новосельцевой

местным аристократом, умершем в 1806 г.» (Plan de réforme de la République de Raguse idéé par M. thomas de Bassegli patricien de la même, mort l'an 1806). Это сочинение, которое автор задумал озаглавить как «Очерк о республике Рагузы» (Essai sur la République de Raguse), написанное по образцу описаний Французских департаментов 1803 г., считается важнейшим в наследии Басельи. Он хотел написать хронику Дубровницкой республики и объяснить причины ее успехов в прошлом, разделив текст на 27 частей с подзаголовками «Далмация и Дубровницкое государство», «Основные принципы законодательства», «Уголовное право», «Кметы», «Сельское хозяйство», «Причины бедности народа», «Общественное воспитание», «Больницы и дома милосердия», «Мореплавание», «Торговля и мануфактуры», «Свободный порт», «Городская и государственная полиция», «Государственные доходы и расходы», «Соледобыча», «О чеканной монете» и т.д. Наиболее оригинальны главы, в которых представлены размышления Басельи о реформах в аристократической республике. С введением меритократии при присвоении дворянства дубровницкая система управления вернулась бы к первоначальному значению греческого слова «аристократия» - «власть лучших». По мнению Басельи, именно наследственная аристократия была источником всех бед, поскольку она превратилась в олигархию, в рамках которой правящее меньшинство преследовало свои цели, не заботясь об интересах народа. См.: Muljačić 1958: 47-56. О франкофильстве Басельи и его восприятии Великой французской революции подробнее см.: Banac 1996. Вдохновленные физиократизмом, воззрения Басельи на экономику и политическую систему Дубровника не стали еще предметом специального исследования.

99 Shek Brnardić 2006.

100 «Разум и время должны вызвать и произвести величайшие изменения и создать в них необратимую сеть; мы должны избегать применения силы, сильные потрясения могут быть очень фатальными для нации. Революции, которые приносит философия, действуют беззвучно, они действуют как природа, с силой, тем более что она бесчувственна» (nеp. $c \phi p$.). Рукопись Т. Басельи под условным названием «Florilegium» см.: Znanstvena knjižnica Dubrovnika. Br. 3. Fol. 169. 


\section{Список сокращений}

DAD - Državni arhiv u Dubrovniku

HAZU - Hrvatska akademija znanosti i umjetnosti

JAZU - Jugoslavenske akademije znanosti i umjetnosti

\section{Литература}

Вульф Л. Изобретая Восточную Европу: карта цивилизации в сознании эпохи Просвещения. М.: Новое литературное обозрение, 2003. 560 с.

Banac 1996 - Banac I. Tomo Baseljić i pitanje dubrovačkih "Frančeza"// Dubrovačka Republika i Francuska revolucija / La République de Dubrovnik (Raguse) et la Révolution française / Ur. M. Foretić. Dubrovnik: Matica hrvatska, 1996. S. 61-71.

Basiljević 1970 - Basiljević T. Bilješke o malim gradovima i o malim državama // Dubrovnik. 1970. № 13. S. 131-137.

Basiljević 2003 - Basiljević T. Rasprava o javnoj korisnosti // Kolo. 2004. № 4. S. 260-269.

Beritić 2000 - Beritić N. O zabranjenim knjigama u Dubrovniku potkraj 18. i početkom 19. stoljeća // Otkrića iz arhiva. Iz književne i političke povjesti Dubrovnika i Dalmacije u 18. i 19. stoljeću. Split: Književni krug, 2000. S. 172-177.

Bersa 2002 - Bersa J. Dubrovačke slike i prilike 1800-1880. Hannover: Hrvatski zapisnik, 2002. $296 \mathrm{~s}$.

Biscaccia 1846 - Biscaccia N. Accademia dei Concordi in Rovigo. Venecija: Pietro Naratovich, 1846.79 p.

Bogišić 1905 - Bogišić V. Dva neizdana pisma Alberta Fortisa o Dubrovniku. Dubrovnik: Srpska dubrovačka štamparija, 1905. $32 \mathrm{~s}$.

Bogišić 1986 - Bogišić R. Akademija "Složnih" (“dei Concordi”) u Dubrovniku 16. stoljeća // Croatica: časopis za hrvatski jezik, književnost i kulturu.1986. Vol. 17. № 24-25. S. 47-68.

Chersa 1824 - Chersa T. Della vita e delle opere di monsignore Giorgio Ferrich. Dubrovnik: Antonio Martecchini, 1824. 43 p.

Ćosić 2003 - Ćosić S. Luka Stulli i dubrovačka književna baština // Anali Zavoda za povijesne znanosti HAZU u Dubrovniku. 2003. № 4. S. 259-286.

Ćosić, Vekarić 2005 - Ćosić S., Vekarić N. Dubrovačka vlastela između roda i države: salamankezi i sorbonezi. Dubrovnik: Zavod za povijesne znanosti HAZU, 2005. $232 \mathrm{~s}$.

Deanović 1933 - Deanović M. Odrazi talijanske akademije "degli Arcadi” preko Jadrana // Rad JAZU. 1933. Knj. 248. S. 1-98.

Franić Tomić 2018 - Franić Tomić V. Prilozi za biografiju Mimi von Born, supruge hrvatskog prosvjetitelja Tome Basseglija // Anali Zavoda za povijesne znanosti HAZU u Dubrovniku. 2018. № 56. S. 299-361. 
Griffiths 1973 - Griffiths D.M. Catherine II: The Republican Empress // Jahrbücher für Geschichte Osteuropas. 1973. № 21. S. 323-344.

Im Hof 1981 - Im Hof U. Der Sozietätsgedanke im 18. Jahrhundert // Pietismus und Neuzeit. 1981. № 7. S. 9-27.

Irmen 1994 - Irmen H.-J. Die Protokolle der Wiener Freimaurerloge "Zur wahren Eintracht”. Frankfurt am Main: Peter Lang, 1994. 451 p.

Janeković Römer 1999 - Janeković Römer Z. Okvir slobode: dubrovačka vlastela između srednjovjekovlja i humanizma. Zagreb: Zavod za povijesne znanosti HAZU u Dubrovniku, 1999. 454 s.

Janeković Römer 2004 - Janeković Römer Z. Otium litterarum, utočište, ishodište // Kolo. 2004. № 4. URL: https://www.matica.hr/kolo/294/otium-litterarum-utociste-ishodiste-20152/ (дата обращения: 10.09.2020).

Janeković Römer 2013 - Janeković Römer Z. Ladanjska Arkadija Junija Antunova de Resti (1755.-1814.) - utočište starog svijeta // Peristil. 2013. №56. S. 207-212. Janeković Römer 2015 - Janeković Römer Z. The Frame of freedom. The nobility of Dubrovnik between the Middle Ages and Humanism. Zagreb: Hrvatska akademija znanosti i umjetnosti, Zavod za povijesne znanosti u Dubrovniku, 2015. $692 \mathrm{p}$.

Kovač 1913 - Kovač K. Zanovićeva škola i framasunstvo u Dubrovniku // List Dubrovačke biskupije. 1913. №. 5. S. 55-57.

Krauss 1967 - Krauss W. "Patriote”, "patriotique”, "patriotism” à la fin de l'Ancien Régime // The Age of Enlightenment / ed. by W. H. Barber. Edinburgh: University Court of the University of St. Andrews, 1967. P. 387-394.

Kunčević 2013 - Kunčević L. Discourses on liberty in early modern Ragusa // Freedom and the Construction of Europe / ed. by Q. Skinner, M. van Gelderen. Cambridge: Cambridge University Press, 2013. Vol. 1. S. 195-214.

Kunčević 2020 - Kunčević $L$. Vrijeme harmonije. O razlozima društvene i političke stabilnosti Dubrovačke Republike. Zagreb: Zavod za povijesne znanosti HAZU u Dubrovniku, 2020. $202 \mathrm{~s}$.

Lonza 2000 - Lonza N. Izborni postupak Dubrovačke Republike // Anali Zavoda za povijesne znanosti HAZU u Dubrovniku. 2000. № 38. S. 9-52.

Lonza 2009 - Lonza N. Kazalište vlasti: Ceremonijal i državni blagdani Dubrovačke Republike u 17. i 18. stoljeću. Zagreb: Hrvatska akademija znanosti i umjetnosti, Zavod za povijesne znanosti u Dubrovniku, 2009. 594 s.

Maixner 1952 - Maixner R. O akademiji Miha Sorkočevića // Građa za povijest književnosti hrvatske. 1952. Knj. 24. S. 57-67.

Muljačić 1955 - Muljačić Ž. Tomo Bassegli. Predstavnik prosvjećenja u Dubrovniku. Dokt. dis. Zagrebu, 1955. (рукопись).

Muljačić 1958 - Muljačić Ž. Tomo Basiljević-Basselji. Pretstavnik prosvjećenja u Dubrovniku. Beograd: Naučno delo, 1958. $114 \mathrm{~s}$.

Muljačić 1959a - Muljačić Ž. Dva priloga povijesti dubrovačkih akademija // Radovi Instituta JAZU u Zadru. 1959. № 4-5. S. 319-340. 
Muljačić 1959b - Muljačić Ž. O strankama u starom Dubrovniku. Prilog povijesti dubrovačkog društva 18. stoljeća // Anali Historijskog instituta JAZU u Dubrovniku. 1959. № 6-7. S. 25-40.

Muljačić 1959c - Muljačić Ž. Salamankezi i sorbonezi u Dubrovniku. Prilog etimologiji naših političkih naziva // Filologija. 1959. № 2. S. 161-173.

Muljačić 1968 - Muljačić Ž. Jedan članak Alberta Fortisa u vezi s Dubrovnikom // Prilozi za književnost, jezik, istoriju i folklor. 1968. № 34. S. 82-89.

Muljačić 1995 - Muljačić Ž. Dubrovački disident i njegov “istražitelj” // Dubrovnik. 1995. № 6. S. 161-168.

Muljačić 1998 - Muljačić Ž. Tomo Baseljić u Göttingenu // Anali Zavoda za povijesne znanosti HAZU u Dubrovniku.1998. № 36. S. 227-247.

Novak 1978 - Novak M. Dubrovnik u drugoj polovici 18. stoljeća // Anali Historijskog odjela Centra za znanstveni rad JAZU u Dubrovniku. 1978. № 15-16. S. $137-181$.

Prijatelj 1996 - Prijatelj K. O portretu Rajmunda Kunića // Anali Zavoda za povijesne znanosti HAZU u Dubrovniku. 1996. № 34. S. 207-214.

Pederin 1983 - Pederin I. Đuro Ferić kao pjesnik hrvatskih fiziokrata i jedan od začetnika hrvatskog narodnog preporoda // Anali Zavoda za povijesne znanosti HAZU u Dubrovniku. 1983. № 3. S. 225-250.

Radoš 2016 - Radoš R. "Lovac smrti i njezinih bolesti”: Dubrovčanin Toma Basiljević (1756.-1806.) // Ljudi 18. stoljeća na hrvatskom prostoru. Od plemića i crkvenih dostojanstvenika do težaka i ribara / ur. L. Čoralić [et al.] Zagreb: Hrvatski institut za povijest, 2016. S. 324-330.

Rezar 2000 - Rezar V. Kratak prilog poznavanju rada Miha Sorga (1739-1796) // Dubrovački horizonti. 2000. № 31. S. 38-64.

Seferović 2015 - Seferović $R$. Politička retorika Francesca Marije Appendinija pred kraj Republike // Anali Zavoda za povijesne znanosti HAZU u Dubrovniku. 2015. № 53/2. S. 311-349.

Shek Brnardić 2006 - Tomo Bassegli: Patriotic musings // Late Enlightenment emergence of the modern "national idea". Vol. 1. / ed. by. B. Trencsényi, M. Kopeček. Budapest: CEU Press, 2006. S. 312-315 (Discourses of Collective Identity in Central and Southeast Europe).

Shek Brnardić 2010 - Shek Brnardić T. Modalities of enlightened monarchical patriotism in the mid-eighteenth-century Habsburg Monarchy // Whose love of which country? Composite states, national histories and patriotic discourses in early modern East Central Europe / ed. by B. Trencsényi, M. Záskaliczky. Leiden: Brill, 2010. S. 631-661.

Shek Brnardić 2013 - Shek Brnardić T. Intelektualni razvoj,// U potrazi za mirom i blagostanjem. Hrvatske zemlje u 18. stoljeću / ur. L. Ćoralić. Zagreb: Matica hrvatska, 2013. S. 195-218.

Stojan 1996 - Stojan S. U salonu Marije Giorgi Bona. Dubrovnik: Zavod za povijesne znanosti HAZU u Dubrovniku, 1996. 197 s. 
Stojan 2016 - Stojan S. Kulturni krug Luke i Miha Sorga (Sorkočevića): glazbenici, pjesnici i diplomati // Anali Zavoda za povijesne znanosti HAZU u Dubrovniku. 2016. № 54. S. 247-262.

Stojan 2018 - Stojan S. Ljetnikovci Rijeke dubrovačke // Vijenac. 2018. № 636638. URL: https://www.matica.hr/vijenac/636\%20-\%20638/ljetnikovci-rijeke-dubrovacke-28117/ (дата обращения: 23.09.2020).

Stolz 2018 - Stolz M. "Otium et Negotium": Reading processes in early Italian and German Humanism // Reading books and prints as cultural objects / ed. by E. Stead. Cham: Palgrave Macmillan. P. 81-106.

Stulli 1834 - Stulli V. Sorgo (Michele Antonio) // Biografia degli Italiani illustri nelle scienze, lettere ed arti. Venecija: Alvisopoli, 1834. Vol. 1. P. 416-417.

Van Dülmen 1996 - Van Dülmen R. Die Gesellschaft der Aufklärer. Zur bürgerlichen Emanzipation und aufklärerischen Kultur in Deutschland. Frankfurt am Main: Fischer, 1996. $206 \mathrm{~s}$.

Verrecchia 1975 - Verrecchia A. Un amico di Lichtenberg: Tommaso Bassegli // Studi Germanici. 1975. № 13. P. 129-139.

\section{References}

Banac, I., 1996. Tomo Baseljić i pitanje dubrovačkih 'Frančeza. In: Foretić, M., ed. Dubrovačka Republika i Francuska revolucija / La République de Dubrovnik (Raguse) et la Révolution française. Dubrovnik: Matica hrvatska, pp. 61-71.

Basiljević, T., 1970. Bilješke o malim gradovima i o malim državama. Dubrovnik, 13, pp. 131-137.

Basiljević, T., 2004. Rasprava o javnoj korisnosti. Kolo, 4, pp. 260-269.

Beritić, N., 2000. O zabranjenim knjigama u Dubrovniku potkraj 18. i početkom 19. stoljeća. In: Otkrića iz arhiva. Iz književne i političke povjesti Dubrovnika $i$ Dalmacije u 18. i 19. stoljeću. Split: Književni krug, pp. 172-177.

Bersa, J., 2002. Dubrovačke slike i prilike 1800-1880. Hannover: Hrvatski zapisnik, $296 \mathrm{p}$.

Biscaccia, N., 1846. Accademia dei Concordi in Rovigo. Venecija: Pietro Naratovich, $79 \mathrm{p}$.

Bogišić, V., 1905. Dva neizdana pisma Alberta Fortisa o Dubrovniku. Dubrovnik: Srpska dubrovačka štamparija, $32 \mathrm{p}$.

Bogišić, R., 1986. Akademija “Složnih” (“dei Concordi”) u Dubrovniku 16. stoljeća. Croatica: časopis za hroatski jezik, knjižeonost i kulturu, 17, 24-25, pp. 47-68.

Chersa, T., 1824. Della vita e delle opere di monsignore Giorgio Ferrich. Dubrovnik: Antonio Martecchini, 43 p.

Ćosić, S., 2003. Luka Stulli i dubrovačka književna baština. Anali Zavoda za povijesne znanosti HAZU u Dubrovniku, 4, pp. 259-286.

Ćosić, S., Vekarić, N., 2005. Dubrovačka vlastela između roda i države: salamankezi i sorbonezi. Dubrovnik: Zavod za povijesne znanosti HAZU, 232 p. 
Deanović, M., 1933. Odrazi talijanske akademije "degli Arcadi” preko Jadrana. Rad JAZU, 248, pp. 1-98.

Franić Tomić, V., 2018. Prilozi za biografiju Mimi von Born, supruge hrvatskog prosvjetitelja Tome Basseglija. Anali Zavoda za povijesne znanosti HAZU u Dubrovniku, 56, pp. 299-361.

Griffiths, D. M., 1973. Catherine II: The republican empress. Jahrbücher für Geschichte Osteuropas, 21, pp. 323-344.

Im Hof, U., 1981. Der Sozietätsgedanke im 18. Jahrhundert. Pietismus und Neuzeit, 7, pp. 9-27.

Irmen, H.-J., 1994. Die Protokolle der Wiener Freimaurerloge "Zur wahren Eintracht”. Frankfurt am Main: Peter Lang, 451 p.

Janeković Römer, Z., 1999. Okvir slobode: dubrovačka vlastela između srednjovjekovlja i humanizma. Zagreb: Zavod za povijesne znanosti HAZU u Dubrovni$\mathrm{ku}, 454 \mathrm{p}$.

Janeković Römer, Z., 2004. Otium litterarum, utočište, ishodište. Kolo, 4. URL: https://www.matica.hr/kolo/294/otium-litterarum-utociste-ishodiste-20152/ (accessed: 10.09.2020).

Janeković Römer, Z., 2013. Ladanjska Arkadija Junija Antunova de Resti (1755.1814.) - utočište starog svijeta. Peristil, 56, pp. 207-212.

Janeković Römer, Z., 2015. The frame of freedom. The nobility of Dubrovnik between the Middle Ages and Humanism. Zagreb: Hrvatska akademija znanosti i umjetnosti, Zavod za povijesne znanosti u Dubrovniku, 692 p.

Kovač, K., 1913. Zanovićeva škola i framasunstvo u Dubrovniku. List Dubrovačke biskupije, 5, pp. 55-57.

Krauss, W., 1967. "Patriote", "patriotique", "patriotism" à la fin de l'Ancien Régime. In: Barber W.H., ed. The Age of Enlightenment. Edinburgh: University Court of the University of St. Andrews, pp. 387-394.

Kunčević, L., 2013. Discourses on liberty in early modern Ragusa. In: Skinner, Q., van Gelderen, M., eds. Freedom and the construction of Europe, 1. Cambridge: Cambridge University Press, pp. 195-214.

Kunčević, L., 2020. Vrijeme harmonije. O razlozima društvene i političke stabilnosti Dubrovačke Republike. Zagreb: Zavod za povijesne znanosti HAZU u Dubrovniku, $202 \mathrm{p}$.

Lonza, N., 2000. Izborni postupak Dubrovačke Republike. Anali Zavoda za pozijesne znanosti HAZU u Dubrovniku, 38, pp. 9-52.

Lonza, N., 2009. Kazalište vlasti: Ceremonijal i državni blagdani Dubrovačke Republike u 17. i 18. stoljeću. Zagreb: HAZU; Zavod za povijesne znanosti u Dubrovniku, $594 \mathrm{p}$.

Maixner, R., 1952. O akademiji Miha Sorkočevića. Građa za povijest književnosti hrvatske, 24, pp. 57-67.

Muljačić, Ž., 1955. Tomo Bassegli. Predstavnik prosvjećenja u Dubrovniku. Dokt. dis. Zagreb. (manuscript). 
Muljačić, Ž., 1958. Tomo Basiljević-Basselji. Pretstavnik prosvjećenja u Dubrovniku. Beograd: Naučno delo, 114 p.

Muljačić, Ž., 1959a. Dva priloga povijesti dubrovačkih akademija. Radovi Instituta JAZU u Zadru, 4-5, pp. 319-340.

Muljačić, Ž., 1959b. O strankama u starom Dubrovniku. Prilog povijesti dubrovačkog društva 18. stoljeća. Anali Historijskog instituta JAZU u Dubrozniku, 6-7, pp. 25-40.

Muljačić, Z., 1959c. Salamankezi i sorbonezi u Dubrovniku. Prilog etimologiji naših političkih naziva. Filologija, 2, pp. 161-173.

Muljačić, Ž., 1968. Jedan članak Alberta Fortisa u vezi s Dubrovnikom. Prilozi za književnost, jezik, istoriju i folklore, 34, pp. 82-89.

Muljačić, Ž., 1995. Dubrovački disident i njegov "istražitelj". Dubrovnik, 6, pp.161-168.

Muljačić, Ž., 1998. Tomo Baseljić u Göttingenu. Anali Zavoda za povijesne znanosti HAZU u Dubrooniku, 36, pp. 227-247.

Novak, M., 1978. Dubrovnik u drugoj polovici 18. Stoljeća. Anali Historijskog odjela Centra za znanstveni rad JAZU u Dubrovniku, 15-16, pp. 137-181.

Prijatelj, K., 1996. O portretu Rajmunda Kunića. Anali Zavoda za povijesne znanosti HAZU u Dubrovniku, 34, pp. 207-214.

Pederin, I., 1983. Đuro Ferić kao pjesnik hrvatskih fiziokrata i jedan od začetnika hrvatskog narodnog preporoda. Anali Zavoda za pozijesne znanosti HAZU u Dubrovniku, 3, pp. 225-250.

Radoš, R., 2016. "Lovac smrti i njezinih bolesti”: Dubrovčanin Toma Basiljević (1756.-1806.). In: Čoralić, L., ed. Ljudi 18. stoljeća na hrvatskom prostoru. Od plemića i crkvenih dostojanstvenika do težaka i ribara. Zagreb: Hrvatski institut za povijest, pp. 324-330.

Rezar, V., 2000. Kratak prilog poznavanju rada Miha Sorga (1739-1796). Dubrovački horizonti, 31, pp. 38-64.

Seferović, R., 2015. Politička retorika Francesca Marije Appendinija pred kraj Republike. Anali Zavoda za povijesne znanosti HAZU u Dubrovniku, 53/2, pp. 311-349.

Shek Brnardić, T., 2006. Tomo Bassegli: Patriotic musings. In: Trencsényi, B., Kopeček, M., eds. Late Enlightenment - emergence of the modern "national idea", 1. Budapest: CEU Press, pp. 312-315 (Discourses of collective identity in Central and Southeast Europe)

Shek Brnardić, T., 2010. Modalities of enlightened monarchical patriotism in the mideighteenth century Habsburg Monarchy. In: Trencsényi, B., Záskaliczky, M., eds. Whose love of which country? Composite states, national histories and patriotic discourses in early modern East Central Europe. Leiden: Brill, pp. 631-661.

Shek Brnardić, T., 2013. Intelektualni razvoj. In: Ćoralić, L., ed. U potrazi za mirom i blagostanjem. Hroatske zemlje u 18. stoljeću. Zagreb: Matica hrvatska, pp. 195-218. 
Stojan, S., 1996. U salonu Marije Giorgi Bona. Dubrovnik: Zavod za povijesne znanosti HAZU u Dubrovniku, 197 p.

Stojan, S., 2016. Kulturni krug Luke i Miha Sorga (Sorkočevića): glazbenici, pjesnici i diplomati. Anali Zavoda za povijesne znanosti HAZU u Dubrovniku, 54, pp. $247-262$.

Stojan, S., 2018. Ljetnikovci Rijeke dubrovačke. Vijenac, 636-638. URL: https:// www.matica.hr/vijenac/636\%20-\%20638/ljetnikovci-rijeke-dubrovacke-28117/ (accessed: 23.09.2020).

Stolz, M., 2018. “Otium et Negotium”: Reading processes in early Italian and German Humanism. In: Stead, E., ed. Reading books and prints as cultural objects. Cham: Palgrave Macmillan, pp. 81-106.

Stulli, V., 1834. Sorgo (Michele Antonio). In: Biografia degli Italiani illustri nelle scienze, lettere ed arti, 1. Venecija: Alvisopoli, pp. 416-417.

Van Dülmen, R., 1996. Die Gesellschaft der Aufklärer. Zur bürgerlichen Emanzipation und aufklärerischen Kultur in Deutschland. Frankfurt am Main: Fischer, $206 \mathrm{p}$.

Verrecchia, A., 1975. Un amico di Lichtenberg: Tommaso Bassegli. Studi Germanici, 13. pp. 129-139.

Vul'f [Wolf], L., 2003. Izobretaia Vostochnuiu Evropu: karta tsivilizatsii v soznanii epokhi Prosveshcheniia [Inventing Eastern Europe: A map of civilization in the mind of the Enlightenment]. M.: Novoe literaturnoe obozrenie, $560 \mathrm{p}$. (in Rus.) 
PhD, Senior Research Fellow, Croatian Institute of History, Zagreb, Croatia. 10000, Opatička 10. E-mail: teashek@gmail.com

\section{The Enlightenment at the end of the Republic of Dubrovnik: Patriotic Society (1793-1794)}

The Patriotic Society, founded in February 1793 by the learned Dubrovnik aristocrat Miho Sorgo (1739-1796), is considered the first true Enlightenment society in the Republic of Dubrovnik. Unlike the previous humanistic and baroque societies, which bore the name "academy" and were all dedicated to literary and linguistic topics, Sorgo's society of amateur scholars was focused on practicality and social engagement. This meant a critical attitude towards the reality of Dubrovnik, and especially towards the ruling aristocratic oligarchy gathered in the Senate, which held a monopoly on political decision-making. Although Europe was undergoing profound social and political transformations at the time, the static nature of Dubrovnik's conservative circles did not allow for any attempts at reform. Owing to this, the society of reformists was very short-lived, lasting only a year. This paper will present an overview of academic sociability in Dubrovnik up to the eighteenth century, as well as the establishment and goals of the Patriotic Society and its members. The topics of preserved speeches will be presented and the role of the aristocrat Tomo Bassegli (1756-1806), whose Enlightenment profile was formed during his stays in Switzerland, Germany and Austria.

Keywords: Enlightenment, patriotism, Republic of Dubrovnik, reforms, sociability, public sphere

How to cite: Shek Brnardić, T., 2021. Prosveshchenie na zakate Dubrovnitskoi respubliki: Patrioticheskoe obshchestvo (1793-1794). Tsentral'noevropeiskie issledovania, 2020, 3(12), pp. 237-268. doi: 10.31168/2619-0877.2020.3.11 